\title{
The relationship between board size and firm performance
}

\author{
CAO Chu yan ${ }^{1,00}$, YANG Zhi hui ${ }^{2, *}$, LIANG Xin ${ }^{3}$ \\ ${ }^{1}$ Department of Management Engineering and Equipment Economics, Naval University of Engineering, Wuhan, China \\ ${ }^{2}$ Institute of Electrical Science and Technology, Naval University of Engineering, Wuhan, China \\ ${ }^{3}$ Department of Management Engineering and Equipment Economics, Naval University of Engineering, Wuhan, China
}

\begin{abstract}
This paper selects 372 companies in the US S\&P 500 from 2013 to 2017 as a sample, and uses empirical research methods to test the relationship between corporate board size and corporate performance. The results show that there is a negative correlation between the size of the board of directors and corporate performance; after dividing the sample into high-tech and non-high-tech industries, the results show that this negative correlation is more prominent in the high-tech field. After classifying the sample according to the parity of the number of directors, the results show that the odd number of directors is more effective than the even number of directors.
\end{abstract}

\section{Introduction}

As the existing research shows, the main function of the board of directors is to supervise managers and provide advice to maximize the wealth of shareholders ${ }^{[1]}$. Existing financial literature studies the effects of various characteristics of corporate boards on the recommendations and supervisory functions of the board of directors. To improve the efficiency of the board of directors, it is important to study the relationship between the size of the board of directors and corporate performance.

The research on the relationship between board size and corporate performance is based on agency theory and resource dependence theory. Specifically, the former assumes that small boards are more effective in maximizing shareholder wealth. Based on agency theory, communication costs, coordination costs and free-riding problems caused by agency problems. A smaller board of directors can reduce these costs, better weigh the pros and cons of agency issues, and ultimately achieve the goal of improving the efficiency of the board. However, based on the resource dependence theory, previous studies support the positive correlation between the board size and corporate performance ${ }^{[2]}$.

In order to study the relationship between corporate board size and corporate performance, this paper selects 372 companies in the US S\&P 500 from 2013 to 2017 for empirical research. In addition to studying the relationship between board size and corporate performance, it also pays attention to the Odd-even effect of corporate board members.

\section{Literature review}

\subsection{Agency issues and the importance of the board of directors}

The separation of ownership and control in modern enterprises may lead to conflicts of interest between directors and managers, which is called agency problems. Due to agency issues, agency costs are paid to managers to encourage them to make decisions on behalf of shareholders.

The agency relationship in corporate governance also creates other problems. Under the condition that the contract for CEO is incomplete and the manager has more professional knowledge, the manager will have the remaining control rights and the opportunity to make selfinterested decisions ${ }^{[3]}$. A reasonable solution to the agency problem is to provide high-level managers with incentive contracts, but if incentive contracts give managers too much power, this will also cause managers to act for their own interests. If the decisions made by managers are not to maximize shareholder wealth, the value of the company will be compromised. In order to maximize shareholder value, it is necessary to solve the agency problem.

The goal of corporate governance is to solve agency problems, and the board of directors is an important part of the corporate governance structure ${ }^{[4]}$. The main function of the board of directors is to supervise management personnel and provide recommendations for the realization of shareholder wealth. In order to ensure the normal work of the board of directors, it is very important to analyze its efficiency. There are many factors that affect the efficiency of the board, such as the size of the board, the composition and diversity of the board. 


\subsection{Board size and corporate performance}

\subsubsection{Board size and corporate performance}

Based on agency theory, researchers believe that the relationship between board size and company performance is negative. A larger board will have more agency costs, and as the board becomes larger, issues such as coordination and communication costs will increase $\mathrm{e}^{[5]}$. It makes sense to consider the factors that affect the board of directors and discover whether the relationship between board size and company value should be positive or negative.

Based on the resource dependence theory, the relationship between board size and corporate governance is positive $\mathrm{e}^{[5]}$. The reason for support is that a larger board of directors can ensure that more non-executive directors can better supervise managers, while a larger board of directors will include more professionals from different fields. High-quality boards from different backgrounds can make better decisions for the board.

Hypothesis 1: There is no relationship between board size and company performance.

\subsubsection{Dynamic analysis of the scale effect of the board of directors}

Based on the above discussion, under different circumstances, the relationship between board size and company performance may be negatively correlated or positively correlated ${ }^{[6]}$. Both parties have empirical research to support their views. According to the costbenefit trade-off relationship of large-scale board of directors, the relationship between board size and company performance in different industries may be different.

According to previous study the negative correlation between board size and company performance is particularly detrimental to industries facing more challenges and a more dynamic environment ${ }^{[7]}$. Specifically, industries that are more innovative, experiencing rapid growth, fierce competition or greater pressure to merge, will have a more significant negative relationship between board size and company performance. This is because these industries need more flexible and efficient boards to cope with rapidly changing business environments, such as rapid technological or regulatory updates. Therefore, it can be expected that the negative correlation between board size and performance in high-tech fields is more significant than in low-tech industries.

Hypothesis 2: The relationship between the size of the board of directors of high-tech companies and non-hightech companies and company performance is the same.

\subsubsection{Odd-even Effects of Corporate Boards}

Directors exercise their rights in the board of directors mainly through the voting process. When decisions are made by voting, directors are affected by performance preferences and herd preferences ${ }^{[8]}$. Performance preferences indicate that the main motivations of directors are consistent with ensuring high-quality board decisions. However, herd preference means that directors' voting decisions are influenced by other directors[8]. In oddnumbered boards, the votes of other even-numbered directors tend to balance each other on average. In an odd number of boards, the problems caused by herd preference will be greatly reduced. The reduction in compliance preferences will lead the board of directors to make higher-quality decisions and more effectively maximize shareholder wealth, while also improving the company's performance.

Hypothesis 3: Odd-even board numbers do not affect corporate performance.

\section{Variable selection and model construction}

\subsection{Sample selection}

Selecting 2013-2017 US S\&P500 companies as samples for empirical analysis. In order to ensure the reliability of the data, the following processing was performed on the data: (1) Excluding financial companies; (2) Excluding the companies in China and Africa that continued to be in the US S\&P 500 from 2013 to 2017 . The final sample obtained in this article is 372 companies in the US S\&P500.

\subsection{Methodology}

According to previous research, the empirical model is as follows:

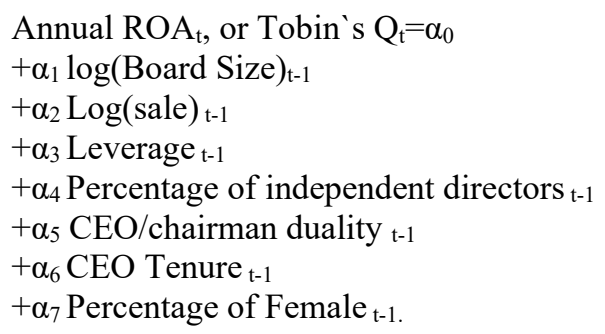

\subsection{Variables and measurement}

\subsubsection{Corporate Performance}

Based on the existing research results, Tobin's $Q$ and ROA are selected as the indicators to measure corporate performance from the perspectives of corporate market value and accounting value, respectively.

\subsubsection{Control variables}

The model in this paper includes six control variables. Choose two control variables to control the past company performance, namely, financial leverage (Leverage) and sales revenue (sale). Corporate financial leverage can show the company's capital structure, which will also affect directors' decision-making and company 
performance. Leverage is equal to total debt divided by total assets. Total debt is a combination of current debt and long-term debt. All information can be collected from Compustat-Capital IQ, and sales revenue is used to control the size of the company.
The other four control variables control the structure and composition of the board. When analyzing the results based on previous studies, the endogenous issues of corporate governance cannot be ignored. In order to alleviate these problems, it is reasonable to control a wide range of company characteristics in regression analysis.

Table1. Definition and calculation of variables

\begin{tabular}{|c|c|c|}
\hline Variable & Code & Definition and calculation \\
\hline Tobin`s Q & TBQ & $\begin{array}{l}\text { The book value of assets minus the book value of equity, plus the market value } \\
\text { of equity, scaled by the book value of assets }\end{array}$ \\
\hline ROA & ROA & $\begin{array}{l}\text { Earnings before interest and tax (PBIT) divided by the book value of assets at the } \\
\text { beginning of the fiscal year }\end{array}$ \\
\hline Leverage & LEV & Total debts divided by total assets \\
\hline Sale & & Sale of the corporation \\
\hline Board Size & BS & The number of directors in the board \\
\hline $\begin{array}{l}\text { Percentage of independent } \\
\text { director }\end{array}$ & PID & $\begin{array}{l}\text { The person who does not have a substantive relationship with the company either } \\
\text { personally or through his or her relatives }\end{array}$ \\
\hline CEO is powerful & CEOP & $\begin{array}{l}\text { A dummy variable, when } \mathrm{CEO} \text { and chairman are the same person in corporation, } \\
\text { this variable equals one }\end{array}$ \\
\hline CEO Tenure & CEOT & How many years the CEO has held the position \\
\hline Percentage of female & PFD & Percentage of female directors \\
\hline
\end{tabular}

\section{Sample statistical description and empirical analysis}

\subsection{Statistical description of the sample}

Table2. Summary Statistics of board and firm.

\begin{tabular}{|c|c|c|c|c|c|c|c|c|}
\hline Variable & Obs. & Mean & Std.dev & Min & $25 \%$ & Med. & $75 \%$ & Max \\
\hline TBQ & 1,627 & 2.265 & 1.355 & 0.968 & 1.349 & 1.837 & 2.729 & 8.531 \\
\hline ROA & 1,627 & 0.156 & 0.086 & -0.289 & 0.101 & 0.148 & 0.202 & 0.897 \\
\hline LEV & 1,634 & 0.221 & 0.152 & 0 & 0.110 & 0.215 & 0.322 & 0.659 \\
\hline Sale & 1,624 & 13260 & 27163 & 22 & 2094 & 5297 & 13090 & 328213 \\
\hline BS & 1,598 & 10.5 & 2.5 & 4 & 9 & 10 & 12 & 22 \\
\hline POID & 1,598 & 0.723 & 0.154 & 0 & 0.636 & 0.75 & 0.833 & 0.938 \\
\hline CEOP & 1,591 & 0.697 & 0.459 & 0 & 0 & 1 & 1 & 1 \\
\hline CEOT & 1,591 & 4.407 & 4.784 & 0 & 1.3 & 2.9 & 5.8 & 34.4 \\
\hline PFD & 1,598 & 0.126 & 0.083 & 0 & 0.083 & 0.111 & 0.182 & 0.375 \\
\hline $\begin{array}{r}\text { Tabl } \\
\text { he total }\end{array}$ & hscer & & regre & & & $\begin{array}{l}4.882 \\
0.111 \\
\end{array}$ & $\begin{array}{l}3.933 \\
0.141\end{array}$ & $\begin{array}{l}0.949 * * * \\
-0.030 * * *\end{array}$ \\
\hline
\end{tabular}
the summary statistics of company performance and company value, company characteristics and board characteristics. The results show that the board size ranges from 4 to 22, with an average of 10.5 and a median of 10 , which is consistent with previous studies. The average ratio of independent directors is $72 \%$.

\subsection{Univariate Analysis}

Table3. Univariate Analysis

\begin{tabular}{llll}
\hline & $\begin{array}{l}\text { Small } \\
\text { Board }\end{array}$ & $\begin{array}{l}\text { Large } \\
\text { Board }\end{array}$ & $\begin{array}{l}\text { Difference } \\
\text { T-test }\end{array}$ \\
\cline { 2 - 4 } & Mean $(1)$ & $\begin{array}{l}\text { Mean } \\
(2)\end{array}$ & $(1)-(2)$ \\
\hline TBQ & 2.584 & 1.959 & $0.625^{* * * *}$ \\
ROA & 0.161 & 0.151 & $0.009^{* *}$ \\
LEV & 0.21 & 0.232 & $-0.022^{* * *}$ \\
$\log ($ sale $)$ & 9.431 & 9.996 & $-0.565^{* * *}$ \\
PID & 0.728 & 0.717 & 0.011 \\
CEOD & 0.664 & 0.73 & $-0.066^{* * *}$
\end{tabular}

Superscripts $* * *, * *$, and $*$ denotes statistical significance at the $1 \%$, $5 \%$, and $10 \%$ levels, respectively.

In the univariate analysis, according to the sample median of 10 , all variables are divided into companies with small-scale boards of directors or large-scale boards of directors. Companies with more than 10 directors on the board of directors are divided into large board groups, and other boards are divided into small board groups. The mean values of variables in each group are listed in columns (1) and (2) of Table 2. The third column shows the difference between columns (1) and (2) and the T test result of the difference.

\subsection{Correlation Matrix}

Table 4 is a correlation matrix showing the correlations between variables. Results show all the correlations are acceptable. These variables will be used in the regression. 
Table4. Correlation Matrix

\begin{tabular}{|c|c|c|c|c|c|c|c|c|c|}
\hline & TBQ & LEV & ROA & $\mathrm{BS}$ & PID & $\log$ (sale) & CEOD & CEOT & PFD \\
\hline TBQ & 1 & & & & & & & & \\
\hline LEV & -0.365 & 1 & & & & & & & \\
\hline ROA & 0.565 & -0.234 & 1 & & & & & & \\
\hline BS & -0.269 & 0.107 & -0.075 & 1 & & & & & \\
\hline PID & 0.026 & -0.016 & 0.057 & -0.056 & 1 & & & & \\
\hline $\log ($ sale $)$ & -0.306 & 0.019 & -0.007 & 0.561 & 0.092 & 1 & & & \\
\hline CEOD & -0.104 & 0.141 & -0.002 & 0.057 & 0.184 & 0.088 & 1 & & \\
\hline CEOT & 0.066 & -0.019 & -0.011 & -0.113 & -0.008 & -0.075 & 0.141 & 1 & \\
\hline PFD & 0.063 & -0.006 & 0.104 & 0.222 & 0.169 & 0.320 & 0.043 & -0.049 & 1 \\
\hline
\end{tabular}

\subsection{Empirical analysis}

Table5. The relation between board size and firm performance.

\begin{tabular}{|c|c|c|c|c|}
\hline & OLS & Cross-sectional & OLS & Cross-sectional \\
\hline \multirow[t]{2}{*}{ Variables } & Tobin`s Q & Tobin`s Q & ROA & ROA \\
\hline & (1) & (2) & (3) & (4) \\
\hline \multirow[t]{2}{*}{$\log (\text { Board Size })_{t-1}$} & $-1.814^{* * *}$ & $-1.966^{* *}$ & $-0.094 * * *$ & $-0.0922288^{*}$ \\
\hline & {$[0.000]$} & {$[0.011]$} & {$[0.000]$} & {$[0.086]$} \\
\hline \multirow[t]{2}{*}{ Firm Size-log (sale) $)_{t-1}$} & $-0.283 * * *$ & $-3.337 * * *$ & $0.029 * * *$ & $-0.138911^{* * *}$ \\
\hline & {$[0.000]$} & {$[0.000]$} & {$[0.000]$} & {$[0.000]$} \\
\hline \multirow[t]{2}{*}{ Leverage $_{t-1}$} & $-1.827 * * *$ & $-0.594 * * *$ & $-0.129 * * *$ & 0.0006684 \\
\hline & {$[0.000]$} & {$[0.000]$} & {$[0.000]$} & {$[0.941]$} \\
\hline \multirow[t]{2}{*}{ PID } & $0.563 * *$ & 0.180 & $0.054 * *$ & -0.0251367 \\
\hline & {$[0.011]$} & {$[0.733]$} & {$[0.001]$} & {$[0.498]$} \\
\hline \multirow[t]{2}{*}{ CEOD $_{t-1}$} & $-0.147 * *$ & -0.274 & 0.002 & 0.013 \\
\hline & {$[0.015]$} & {$[0.104]$} & {$[0.667]$} & {$[0.269]$} \\
\hline \multirow[t]{2}{*}{$\mathrm{CEOT}_{\mathrm{t}-1}$} & $0.021 * * *$ & 0.007 & 0.000 & -0.000 \\
\hline & {$[0.000]$} & {$[0.653]$} & {$[0.474]$} & {$[0.697]$} \\
\hline \multirow[t]{2}{*}{$\operatorname{PFD}_{t-1}$} & $1.553 * * *$ & $3.678 * * *$ & 0.030 & $0.151 * *$ \\
\hline & {$[0.000]$} & {$[0.000]$} & {$[0.253]$} & {$[0.014]$} \\
\hline \multirow[t]{2}{*}{ Constant $_{t-1}$} & $5.514 * * *$ & $10.335^{* * *}$ & $-0.096^{*}$ & $0.265^{* * *}$ \\
\hline & {$[0.000]$} & {$[0.000]$} & {$[0.053]$} & {$[0.000]$} \\
\hline Year FE & Yes & & Yes & \\
\hline Industry FE & Yes & & Yes & \\
\hline Observations & 1585 & 326 & 1585 & 326 \\
\hline $\mathrm{R}^{2}$ & 0.619 & 0.319 & 0.539 & 0.213 \\
\hline
\end{tabular}

All continuous variables are winsorized as the 1 st and 99 th percentiles, and all independent variables are lagged one year. Superscripts $* * *, * *$, and $*$ denotes statistical significance at the $1 \%, 5 \%$, and $10 \%$ levels, respectively.

In Table 5, all regressions (1) to (4) show the negative correlation between board size and company performance. This result is consistent with many previous studies, and smaller boards can operate more efficiently. The negative relationship between board size and company performance is also in line with expectations. For the sample companies, these companies are based on the principle of cost-effectiveness, and tend to reduce their costs when measuring the benefits and costs of large-scale board of directors. The impact of board size on company performance is dynamic, and more tests should be conducted to discuss the relationship between board size and company performance.

Table6. Subsample analysis

\begin{tabular}{lllll}
\hline Variables & High-tech & Low-tech & High-tech & Low-tech \\
\hline & $(1)$ & $(2)$ & $(3)$ & $(4)$ \\
\hline
\end{tabular}




\begin{tabular}{|c|c|c|c|c|}
\hline \multirow[t]{2}{*}{ Odd $_{t-1}$} & & & $0.254^{*}$ & 0.013 \\
\hline & & & {$[0.092]$} & {$[0.835]$} \\
\hline \multirow[t]{2}{*}{$\log ($ Board Size $) t-1$} & $-3.157 * *$ & $-1.504 * * *$ & $-2.046^{* *}$ & $-1.499 * * *$ \\
\hline & {$[0.034]$} & {$[0.000]$} & {$[0.044]$} & {$[0.000]$} \\
\hline \multirow[t]{2}{*}{ Firm Size-log (sale) $)_{t-1}$} & $-0.907 * * *$ & $-0.528 * * *$ & $0.254^{*}$ & 0.013 \\
\hline & {$[0.000]$} & {$[0.000]$} & {$[0.092]$} & {$[0.835]$} \\
\hline \multirow[t]{2}{*}{$\mathrm{LEV}_{\mathrm{t}-1}$} & $-2.838 * * *$ & $-2.797 * * *$ & $-2.046 * *$ & $-1.499 * * *$ \\
\hline & {$[0.000]$} & {$[0.000]$} & {$[0.044]$} & {$[0.000]$} \\
\hline \multirow[t]{2}{*}{ PID $_{t-1}$} & -0.215 & 0.006 & $-0.916^{* * *}$ & $-0.528 * * *$ \\
\hline & {$[0.732]$} & {$[0.979]$} & {$[0.000]$} & {$[0.000]$} \\
\hline \multirow[t]{2}{*}{ CEOD t-1 } & -0.254 & -0.042 & $-2.866^{* * *}$ & $-2.795 * * *$ \\
\hline & {$[0.164]$} & {$[0.552]$} & {$[0.000]$} & {$[0.000]$} \\
\hline \multirow[t]{2}{*}{ CEOT $_{\mathrm{t}-1}$} & -0.007 & $0.011^{*}$ & -0.174 & 0.007 \\
\hline & {$[0.735]$} & {$[0.081]$} & {$[0.781]$} & {$[0.977]$} \\
\hline \multirow[t]{2}{*}{$\operatorname{PFD}_{t-1}$} & $5.456 * * *$ & $2.492 * * *$ & -0.267 & -0.043 \\
\hline & {$[0.000]$} & {$[0.000]$} & {$[0.143]$} & {$[0.551]$} \\
\hline \multirow[t]{2}{*}{ Constant $t-1$} & $13.196^{* * *}$ & $9.086 * * *$ & -0.005 & $0.011 *$ \\
\hline & {$[0.000]$} & {$[0.000]$} & {$[0.807]$} & {$[0.082]$} \\
\hline Year FE & Yes & Yes & $5.599 * * *$ & $2.491 * * *$ \\
\hline Industry FE & & & {$[0.000]$} & {$[0.000]$} \\
\hline Observations & 298 & 1287 & $13.014 * * *$ & $9.074 * * *$ \\
\hline $\mathrm{R}^{2}$ & 0.324 & 0.216 & {$[0.000]$} & {$[0.000]$} \\
\hline
\end{tabular}

According to Table 6 (1) (2), Comparing the results of non-high-tech and high-tech companies, the coefficient between the board size of high-tech companies and corporate performance is -3.157484 , which is much lower than -1.504 for low-tech companies. A $10 \%$ increase in the board size of a high-tech company will cause Tobin's $\mathrm{Q}$ to drop by 0.316 . However, for non-high-tech companies, if the size of the board of directors increases by $10 \%$, the corporate value will only decrease by about 0.1504 . The difference between high-tech companies and low-tech companies shows that changes in the board size of high-tech companies have a much greater impact on corporate performance than low-tech companies. One possible reason for the difference in coefficients between high-tech and low-tech companies is that high-tech industries need flexible and effective boards to keep up with the rapid development of these industries, and smaller-scale boards are more flexible than large-scale boards.

The results in table 6 regression (3) and (4) show that after controlling for board size and other factors that determine company performance, boards with odd members are more effective than even boards, and also support the assumption that more effective boards are needed in the face of rapidly developing high-tech industries.

\section{Conclusion}

Through the above empirical analysis, it can be seen that based on the data of 327 companies in the US S\&P500 from 2013 to 2017, the size of the board of directors has a negative correlation with corporate performance. After considering industry factors, the size of the board of directors in the high-tech industry has a more significant impact on corporate performance. Further testing the effect of the even-numbered nature of the board of directors on corporate performance shows that an oddnumbered board of directors is more effective than an even-numbered board. This shows that for companies, based on the agency problem principle, a smaller board of directors can to a certain extent have better decisionmaking efficiency, which is conducive to the improvement of corporate performance.

\section{References}

1. Pfeffer, J. (1973) Size, composition, and function of hospital boards of directors: A study of organizationenvironment linkage. Administrative Science Quarterly, pp.349-364.

2. Liu, Y., Miletkov, M., Wei, Z. and Yang, T. (2015) Board independence and firm performance in China. Journal of Corporate Finance, 30, pp.223-244.

3. Wintoki, M., Linck, J. and Netter, J. (2012) Endogeneity and the dynamics of internal corporate governance. Journal of Financial Economics, 105(3), pp.581-606.

4. Yermack, D. (1996) Higher market valuation of companies with a small board of directors. Journal of Financial Economics, 40(2), pp.185-211.

5. Ahmad, R., Said, R., \& Arsad, S. (2017) The board governance mechanism and the effect of concentration ownership on Malaysia companies performance. International Journal of Academic Research in Business and Social Sciences, 7(2), 757768. 
6. Bhatt, P. R., \& Bhatt, R. R. (2017) Corporate governance and firm performance in Malaysia. Corporate Governance: The International Journal of Business in Society, 17(5), 896-912.

7. Dang, C., \& (Frank) Li, Z., \& Yang, C. (2018) Measuring firm size in empirical corporate finance. Journal of Banking \& Finance, 86(519), 159-176.

8. Deng, X., Gao, H. and Liu, W. (2012) Voting Efficiency and the Even-Odd Effects of Corporate Board: Theory and Evidence. SSRN Electronic Journal. 